University of Michigan Law School

University of Michigan Law School Scholarship Repository

1920

\title{
Effect of an Agreement by One Person to Supply Another's 'Requirements' of a Given Commodity
}

Grover C. Grismore

University of Michigan Law School

Available at: https://repository.law.umich.edu/articles/1244

Follow this and additional works at: https://repository.law.umich.edu/articles

Part of the Contracts Commons

\section{Recommended Citation}

Grismore, Grover C. "Effect of an Agreement by One Person to Supply Another's 'Requirements' of a Given Commodity." Mich. L. Rev. 18 (1920): 409-11.

This Response or Comment is brought to you for free and open access by the Faculty Scholarship at University of Michigan Law School Scholarship Repository. It has been accepted for inclusion in Articles by an authorized administrator of University of Michigan Law School Scholarship Repository. For more information, please contact mlaw.repository@umich.edu. 
Effect of an Agreement by One Person, to Supply Another's "KeQUIREMENTS" OF A GIVEN Com ModiTy.-The cases show that the kind of agreement indicated by the heading of this note has become an established part of business usage. In normal times such an agreement is likely to be carried out to the entire satisfaction of both parties, without question, but, in a period of changing business conditions and abnormal price fluctuations such as we have witnessed diring the last few years, nice questions of interpretation are likely to arise, as is well illustrated by the recent case of Oscar Schlegel Mfg. Co. v. Peter Cooper's Glue Factory, (1920) I79 N. Y. S. 271.

The defendant agreed to supply the plaintiff with its "requirements of "Special BB' glue for the year 1916" at nine cents per pound, deliveries to be made as ordered by it. The plaintif was a jobber and, as defendant well knew, bought only for re-sale to the trade. When it received an order for glue it sent a requisition to the defendant which filled it. Similar contracts had been entered into by the parties for each of the four years immediately preceding the contract in question. During that time the price of glue fad remained stable, and plaintiff had secured orders for from sixty to seventy barrels, of 500 pounds each, per year. During the latter part of the year 19r6, the price of glue went steadily upward from nine to twenty-five cents per pound. The plaintiff, evidently not averse to doing a little profiteering, having increased its sales force from eight to eighteen, pushed the sale of glue to such an extent-sometimes apparently by offering it at a substantial reduction from the prevailing market price-that it succeeded in getting orders amounting, for the year, to three hundred and forty barrels. Defendant shipped one hundred and thirty barrels but refused to supply the balance, and when sued, resisted a recovery on two grounds, viz., (1) that the agreement was not binding for want of mutuality. (2) that in any event the word "requirements," properly interpreted, meant simply that defendant was to supply glue to an amount substantially equivalent to what had been ordered by the plaintiff during the preceding year. Both points were resolved against the defendant by a divided court.

It seems quite obvious that in the proper interpretation of the word "requirements," as used in the agreement, is to be found the correct solution of both of the problems suggested by the defendant. According to the usual definition given by standard dictionaries the word may be used in eitner 
one of two distinct senses. It may mean ( 1 ) the act of requiring or demanding, (2) something requircd or needed. If the word is to be interpreted in the sense first indicated, then it is clcar that the agreement is not a contract for want of a sufficient consideration to support the seller's promise. If the buyer agrees to take only what he requires in the sense of what he 'demands' or calls for, his promise is wholly illusor;, since it amounts to no more than saying that he will do what he will do. See American etc. Co. v. Kirk, 68 Fed. 79r; Teipel v. Meyer, 106 Wis. 41 ; Cold Blast Transp. Co. v. K. C. Bolt and Nut Co., 114 Fed. 77. But if it is to be interpreted in the second sense to mean that the buyer will take from the seller what he needs, then there is consideration, for if he buys what he needs from the seller, he necessarily gives up the right to buy elsewhere and consequently suffers a legal detriment. Following the principle which says that a "contract, if capable of two equally reasonable inierpretations, should be given that interpretation which will tend to support it," (Lurton, J., in Lime Locomotive etc. Co. v. National etc. Co., 155 Fed. 77 ) the courts have quite generally upheld such agreements. Minnesota Lumber Co. v. Whitebreast Coal Co., 160 I11. $85 ; T$. W. Jenkins \& Co. v. Anaheim Sugar Co., 247 Fed. 958, and cases therein cited. Courts have at times assumed that, because of a supposed requirement of mutuality, this result would follow only in a case where the agreement is made in connection with an established business, having needs capable of reasonably definite pre-estimate; and have held that the agreement is unenforcible where, as in the principal case, the buyer buys for re-sale only and is in such a position as to make it uncertain whether or not he will need any of the commodity at all. T. W. Jenkins Co. v. Anaheim Sugar Co., 237 Fed. 278, commented on in 15 Mich. L. Rev. 44I, reversed 247 Fed. 958; Crane v. Crane \& Co., 105 Fed. 869. The same supposed requirement has in a few cases been relied upon as a basis for the holding that the buyer impliedly promises to continue his business for the period during which the contract, by its terms, is to continue in force-the theory being that if he continues in business he will need a quantity of the commodity, and thus there will be present the requisite mutuality: Hickey v. O'Brien, I23 Mich. 6II; Wells v. Alexandre, 130 N. Y. 642 ; Loudenback Fertilizer Co. v. Tenn. Phosphate Co., I21 Fed. 298. Such decisions are clearly erroneous. All that the phrase "mutuality of obligation" can legitimately be held to mean in this connection is, that to make a bilateral agreement enforcible as a contract, each side must furnish a consideration. In accord with the principal case on this point are the following: T.W. Jenkins Co. v. Anaheim Sugar Co., supra; Ramey Lumber Co. v. John Schroeder Lumber Co., 237 Fed. 39; MiKeever etc. Co. v. Canonsburg Iron Co., $138 \mathrm{~Pa}$. St. 184; Western Macaroni Mfg. Co. v. Fiore, 47 Utah 108. The anomalous decisions just referred to have apparently resulted from a belief on the part of some courts that they were necessary to prevent a gross injustice being perpetrated upon the seller. They have thought that without the requirement of mutuality, as they interpreted it, the seller would be wholly at the mercy of the buyer. Disregarding the obvious argument that the seller entered into the agreement with his eyes open, which after all is not an answer to the position taken, there seems 
to be another means of accomplishing the result aimed at-the protection of the seller-which is perfectly consistent with the fundamental principles of contract law.

The word, "requirements," as used in the agreement, is capable of and demands further interpretation to determine the extent of the obligation of the buyer and the seller respectively. In other words, does the word, "requirements," connote that the buyer will take and the se!ler will furnish any quantity, however large or small, that the buyer may need in any conceivable contingency which may arise; or does it indicate a quantity variable within certain somewhat indefinite but nevertheless real limits,-the quantity purposely being left indefinite by the parties because of the uncertainty due to normal fluctuations in needs. Either use of the word would seem to be legitimate. It does not require any stretch of the imagination to see that when the seller agrees to furnish to another, who is engaged in a business with which the former is familiar, "his requirements," he has in mind a quantity capable of fairly definite pre-estimate. The word may be intended as the equivalent of the statement of a definite quantity qualified with the words "more or less," which it is held merely provide against slight and accidental variations. Hills v. Edmund Pcycke Co., 14 Cal. App. 32; Geiger v. Kaesiner, 148 Ill. App. 529; Santa Paula Commercial Co. v. Parkhurst-Davis Mercantile Co., 86 Kan. 328; Little Rock Cooperage Co. v. Gunncls, 82 Ark. 286.

Obviously no a priori rule can be laid down for determining in a particular case which interpretation is the correct one. This must depend upon the apparent intention of the parties to be deduceci from all the circumstances surrounding the transaction. If it appears that the obligation was reasonably understood to be unlimited, there is no valid reason why it should not be enforced in that way, but, on the other hand, if it was not so understood, then justice and common sense alike demand that it be not so enforced. As is said in Poliock on Contracrs (3rd Am. Ed.) 308, 309, "We must look to the state of things as known to and affecting the parties at the time of the promise, including their information and competence with regard to the matter in hand, and then see what expectation the promisor's words, as uttered in that state of things, would have created in the mind of a reasonable man in the promisee's place and with the same means of judgment." Viewed from this angle the conclusion of the majority of the court in the principal case would seem to be erroneous. If all the circumstances are taken into account it is difficult to suppose that the plaintiff could reasonably have believed that the defendant intended to bind itself to supply an unlimited quantity. For a case apparently taking the view here suggested see $T . W$. Jenkins Co. v. Anahein Sugar Co., 247 Fed. 958, 962 (semble). On this basis the result in such cases as Hickey v. O'Brien, Wells v. Alexandre, and Loudenback Fertilizer Co. v. Tenn. Phosphate Co., cited supra, becomes intelligible. Where the facts show that the buyer is to make a special effort to push the sale of the seller's product then such a limitation on the seller's obligation obviously should not and does not exist. See New York Central Iron Works v. U. S. Radiator Co., 174 N. Y. 331. G. C. G. 